\title{
Improving The Ability of Class Teachers in Developing Student Work Sheets Learning From Home Program Through Mentoring
}

\author{
${ }^{1}$ Dwi Nartati, ${ }^{2}$ Ana Andriani \\ \{dwinartati1203@gmail.com, Ana.Andriani@gmail.com\} \\ Program Studi Pendidikan Dasar, Universitas Muhammadiyah Purwokerto
}

\begin{abstract}
This study aims to improve the skills of class teachers in the preparation of Student Worksheet for Home Learning Program through Mentoring at Elementary School 3 Kebutuhduwur, District Pagedongan Banjarnegara, academic year 2020/2021. In the initial conditions, the class teachers at Elementary School 3 Kebutuhduwur were not able to compile the Student Worksheet for the Home Learning Program, with an average score of 58.75. This research is a school action research conducted collaboratively with collaborators. The research design used a modified Kemmis \& McTaggart model in 2 cycles consisting of planning, implementing, observing, and reflecting. The research subjects included 6 class teachers at Elementary School 3 Kebutuhduwur. The research object is the teacher's ability to plan lessons and workshops. Data co llection techniques are tests and observations. The data were analyzed using descriptive quantitative and qualitative techniques. The results showed that the competence of class teachers in preparing Student Worksheets for Home Learning Program had increased from the initial condition which was only 58.75, increased to 73.96 in cycle I and increased again in Second Cycle to 83.75. And the completeness of class teachers in preparing Student Worksheets for Home Learning Program has increased from the initial conditions which only $0 \%$ increased to $67 \%$ in cycle I and increased again in Second Cycle to $100 \%$.
\end{abstract}

Keywords: Teacher ability, Student Worksheet Home Learning Program, mentoring

\section{Introduction}

In community life, the school serves as an agent for the application of learning, education, and training. A high-quality school correlates with higher-quality human resources. The higher the quality of a school, the better the inputs, processes, and outputs. In addition to providing knowledge, the teacher's role is to provide moral education to students. Because the teacher is a role model and a role model in the community, the public will see how the teacher's daily actions reflect his or her attitude [1]. Law Number 20 of 2003 concerning the Basics, Functions and Objectives of National Education, namely "National Education functions to develop capabilities and shape the character and civilization of a nation with dignity in order to educate the nation's life, aims to develop the potential of students to become human beings who believe and fear God Almighty, has noble character, is healthy, knowledgeable, capable, creative, and becomes a democratic and responsible citizen. The teacher as a transformer in learning does not only convey knowledgeable subject matter, but there is another side that must be given to students, namely attitudes and skills. 
The learning environment in the new academic year 2020/2021 does not allow for normal learning [2]. The COVID-19 19 or Coronavirus Disease epidemic that has ravaged the entire world has had a significant impact on all sectors, including education. Learning cannot take place in schools due to the threat of the corona virus, which spreads quickly. The Circular of the Minister of Education and Culture of the Republic of Indonesia Number 4 of 2020 concerning the Implementation of Education Policies in an Emergency the Spread of Coronavirus disease (Covid-1 9) explains that the Learning from Home Process is carried out with the following conditions:

1. Learning from Home through online / distance learning is carried out to provide meaningful learning experiences for students, without being burdened with demands to complete all curriculum achievements for grade promotion and graduation;

2. Learning from Home can be focused on life skills education, including regarding the Covid19 pandemic;

3. Learning from Home learning activities and assignments may vary between students, according to their respective interests and conditions, including considering gaps in access/ learning facilities at home;

4. Evidence or the product of Learning from Home activities is given good qualitative and useful feedback from the teacher, without being required to give a quantitative score.

Guidelines for organizing learning in the new academic year during the Covid-19 pandemic refer to the principles of education policy during the pandemic, especially the health and safety of students, educators, education personnel, families, and communities, which are the highest priorities in developing policies and implementing learning [3]. The Minister of Education and Culture also revised the Guidelines for Implementing Learning in the New Academic Year and the Academic Year During the Covid-19 Pandemic. Face-to-face learning is prohibited in Education Units in the Yellow, Orange, and Red Zones. Banjarnegara Regency in the 2020/2021 school year is still in the orange zone so that learning is carried out remotely which is then for the primary school level using the term Learning from Home. The Circular of the Head of the Education, Youth and Sports Office of Banjarnegara Regency Number 421.2 / 5213 / Dikpora / 2020 refers to the Joint Decree of 4 ministers, for the SD / MI level in Banjarnegara Regency still implementing Learning from Home so that the preparation of teaching materials is made using a package system. Each package is used for BDR for 1 week.

The factors causing the low ability of class teachers in the preparation of Student Worksheets for the Home Learning Program include [4]: 1) have never attended education and training whose material is specifically for the preparation of Student Worksheets for the Learning From Home, 2) the principal has never provided special guidance on the procedures for preparing Student Worksheets for the Home which are in accordance with the situation and conditions of the development of Covid 19,3) Teacher Working Group activities have never discussed the procedures for drafting Student Worksheet for Home Learning Program for the emergency Covid 19 period) is in accordance with the correct rules for preparing Student Worksheets Learning for Home. 
Referring to this policy, it is necessary to provide Mentoring by the Principal in compiling Student Worksheets for the Home Learning Program in order to improve the ability of teachers so that student activities while learning from home are not hampered. To all educators Preparation of Student Worksheets from Home Learning Programs that are in accordance with the student's immediate environment and do not burden the student's parents / guardians, namely helping parents [5]. Mentoring is a learning process on the form of mutually supportive relationship in supervision between people who have better skill and abilities to people who do not know in order to convey new knowledge to make it better. There are several advantages of implementing Mentoring, namely: 1) complex problems can become simple; 2) difficult work can be made easy; 3 ) establishing fraternity, friendship, and friendship between teachers and the principal of Elementary School; and 4) the learning process becomes meaningful as a positive impact of the compilation of student work sheets Home Learning Program.

To answer the discourse, it is deemed necessary $n$ School Action Research for the principal of Elementary School 3 Kebutuhduwur with the title "Improving the Ability of Class Teachers in developing Student Worksheets Learning program from Home Program through Mentoring“. This title is very much in accordance with the current situation and conditions, namely the corona virus outbreak that has hit globally throughout the world, including in the world of education.

\section{Research Methods}

The type of research used is school action research. Mulyasa stated that School Action Research is an effort to improve the education system's performance in developing school management to be more productive, effective and efficient [6]. School management decrease or is not optimal, thus hampering quality improvement. The form of research used in this school action research is a form of collaborative research, namely research involving the principal himself assisted by another principal in the observation. In this case the researcher acts as a researcher and is assisted by colleagues as observers.

This study uses a Classroom Action Research (CAR) design. The model used is the Kemmis \& Taggart model, a research model that uses 4 stages including planning, implementation or action, observation or observation, and reflection or reflection [7]. This action research was carried out with a recycling process carried out in 4 stages, as seen in the following figure: 


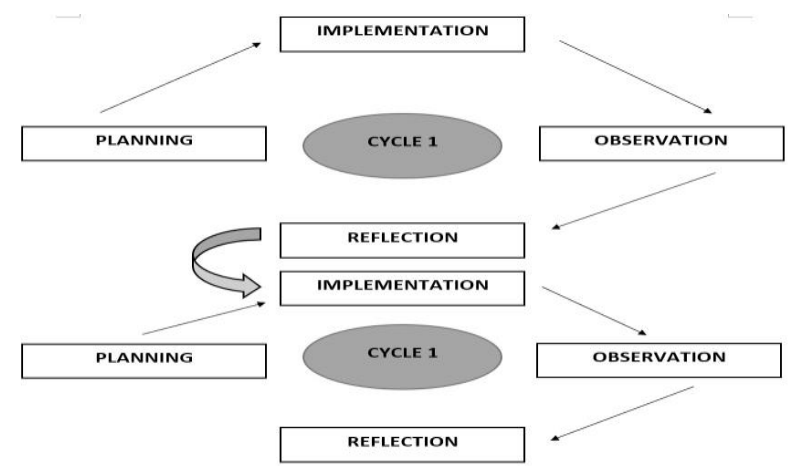

Figure 1. Action research design model Kemmis and MC. Taggart in Arikunto (2008: 16).

The subjects in this study consisted of 6 class teachers at Elementary School 3 Kebutuhduwur, District Pagedongan, Banjarnegara. This school action research was conducted at Elementary School 3 Kebutuhduwur, District Pagedongan, Banjarnegara for 3 moths.

This action research procedure is described as follows.

1). Planning

In this plan, what researchers do is prepare observation sheets, compile Student Worksheets and Home Learning Program.

2). Actions and Observations

In the observation action stage, collaborators observe and record the results of their observations on Mentoring in the preparation of Student Worksheets for Home Learning Program

3). Reflection

After completing the observation, the researcher reflected. Researchers convey the shortcomings of teachers in preparing lesson plans. Researchers assist teachers in preparing Student Worksheets for the Home Learning Program that are good and correct.

To obtain complete data, researchers used several techniques. The techniques used include observation, performance tests in the form of question cards and documentation:

1). Observation technique according to Sutrisno Hadi in Sugiyono is a technique of collecting data through an observation, accompanied by notes on the state or behavior of the target object [8]. Observations were were carried out in $1^{\text {st }}$ cycle and $2^{\text {nd }}$ by going directly to the field actively to get a real picture and information about the teacher's ability to compile the Student Worksheet for the Learning from Home Program at Elementary School 3 Kebutuhduwur, District Pagedongan Banjarnegara.

2). The test, according to Nurgiyantoro is a systematic instrument or procedure for measuring a sample of behaviour [9]. In this study, using the results of question cards (attached) to measure the ability of teachers in the preparation of Student Worksheets Home Learning Program.

3). The documentation technique according to Sugiyono (2018: 240) is a record of past events. In collecting this document, the researchers focused on the archive of Student Worksheet for Home Learning Program that had been compiled by teachers at Elementary School 3 Kebutuhduwur, District Pagedongan, Banjarnegara.

Researchers set performance indicators as the success target to be achieved in this school action research activity, namely 75 as the success target to be achieved. The researcher determined that 
75 percent of teachers at Elementary School 3 Kebutuhduwur, District Pagedongan Banjarnegara had a minimum score of 75 in preparing the Student Worksheet for the Home Learning Program.

\section{Results and Discussion}

\subsection{Pre-Cycle}

The data on the score obtained from observations by the Principal of 6 classroom teachers can be seen in the table as follows:

Table 1 - Assessment of Tasks in Pre Cycle

\begin{tabular}{ccc}
\hline No & Teacher & Scores \\
\hline 1 & Class I & 62,50 \\
2 & Class II & 65,00 \\
3 & Class III & 46,25 \\
4 & Class IV & 51,25 \\
5 & Class V & 62,50 \\
6 & Class VI & 65,00 \\
\hline & Average & $\mathbf{5 8 , 7 5}$ \\
\hline & Completeness & $\mathbf{0 \%}$
\end{tabular}

The average ability of all class teachers ( 6 teachers) indicates have not mastered the technique of compiling the Student Work Sheet from Home Learning Program properly. Meanwhile, teachers who achieved the minimum level of completeness were $(0 \%)$. Researchers tried to improve the ability of class teachers in preparing Student Worksheets for Home Learning Program through mentoring.

\subsection{First Cycle}

\subsubsection{Planning}

Planning carried out by researchers at Elementary School 3 Kebutuhduwur, Pagedongan Subdistrict, Banjarnegara Regency is 1) compiling a mentoring plan, 2) compiling a schedule of activities, 3) determining teachers to be researched, 4) compiling attendance lists, 5) preparing the room and equipment needed, 6) preparing materials, 7) preparing documentation. The implementation of classroom teacher Mentoring in the preparation of the Student Worksheet Home Learning Program will be carried out in two cycles.

\subsubsection{Implementation}

The implementation of classroom teacher mentoring activities in the preparation of the Student Worksheet for the First Cycle of Home Learning Program consists of two meetings. At the first meeting, the presentation of material for the preparation of the Student Worksheet for the Home Learning Program was carried out. At the second meeting, the training steps carried out are the same as in meeting 1

\subsubsection{Observation}

After mentoring was carried out, the results of the ability of the Elementary School 3 Kebutuhduwur class teachers in compiling Student Worksheets for Home Learning Program in first cycle were as follows: 
Table 2 - Results of Classroom Teachers' Ability in Preparing First Cycle Program Worksheets

\begin{tabular}{lcc}
\hline No & Teachers & Value \\
\hline 1 & Class I & 76,25 \\
2 & Class II & 75,00 \\
3 & Class III & 67,50 \\
4 & Class IV & 68,75 \\
5 & Class V & 77,50 \\
6 & Class VI & 78,75 \\
\hline & Average & $\mathbf{7 3 , 9 6}$ \\
\hline & Completeness & $\mathbf{6 7 \%}$ \\
\hline
\end{tabular}

\subsubsection{Reflection}

The results of the analysis show that the first cycle action through mentoring began to be favored by class teachers in the preparation of Student Worksheets for Home Learning Program. However, there are 2 teachers whose scores have not reached the minimum completeness, namely 75. So, action is needed in Second Cycle by improving mentoring such as from classical mentoring to individual mentoring.

\subsection{Cycle II}

3.3.1 Planning

The planning carried out by the researcher is 1) compiling a mentoring plan, 2) compiling a schedule of activities, 3) determining the teacher to be studied, 4) compiling an attendance list, 5) preparing the room and equipment needed, 6) preparing the material, 7) preparing documentation. Implementation of classroom teacher Mentoring in making Student Worksheets for the Home Learning Program

\subsubsection{Implementation}

The implementation of classroom teacher mentoring activities in preparing Student Worksheets for the Second Cycle of Home Learning Program consists of two meetings. The training steps carried out were the same as those carried out in first cycle.

\subsubsection{Meeting 2}

In the second cycle, the second meeting was held on Thursday, August 13, 2020. At the second meeting, the delivery of material and training for the preparation of the Student Worksheet for the Home Learning Program was carried out. The training steps carried out are the same as those carried out in the first cycle of observation. After mentoring was carried out, the results of the ability of class teachers at Elementary School 3 Kebutuhduwur in compiling Student Worksheets for the Home Learning Program in Second Cycle were as follows: 
Table 4 - Results of Classroom Teachers' Ability in Preparing Second Cycle Program Worksheets

\begin{tabular}{ccc}
\hline No & Teacher & Value \\
\hline 1 & Class I & 83.75 \\
2 & Class II & 82.50 \\
3 & Class III & 80.00 \\
4 & Class IV & $8 ., 50$ \\
5 & Class V & 86.25 \\
6 & Class VI & 87.50 \\
\hline \multicolumn{3}{c}{ Average } \\
\hline
\end{tabular}

From the table above we can see all the teachers who have met the minimum score of 75 or completeness reached $100 \%$.

The increase in the average ability of class teachers in preparing Student Worksheets for Home Learning Program in Second Cyclewas 9.79 points. From 73.96 in the first cycle, it increased to 83.75 in the second cycle. To be clearer, the increase in the ability of classroom teachers in preparing Student Worksheets for the Home Learning Program in Second Cycle can be illustrated in Figure 2:

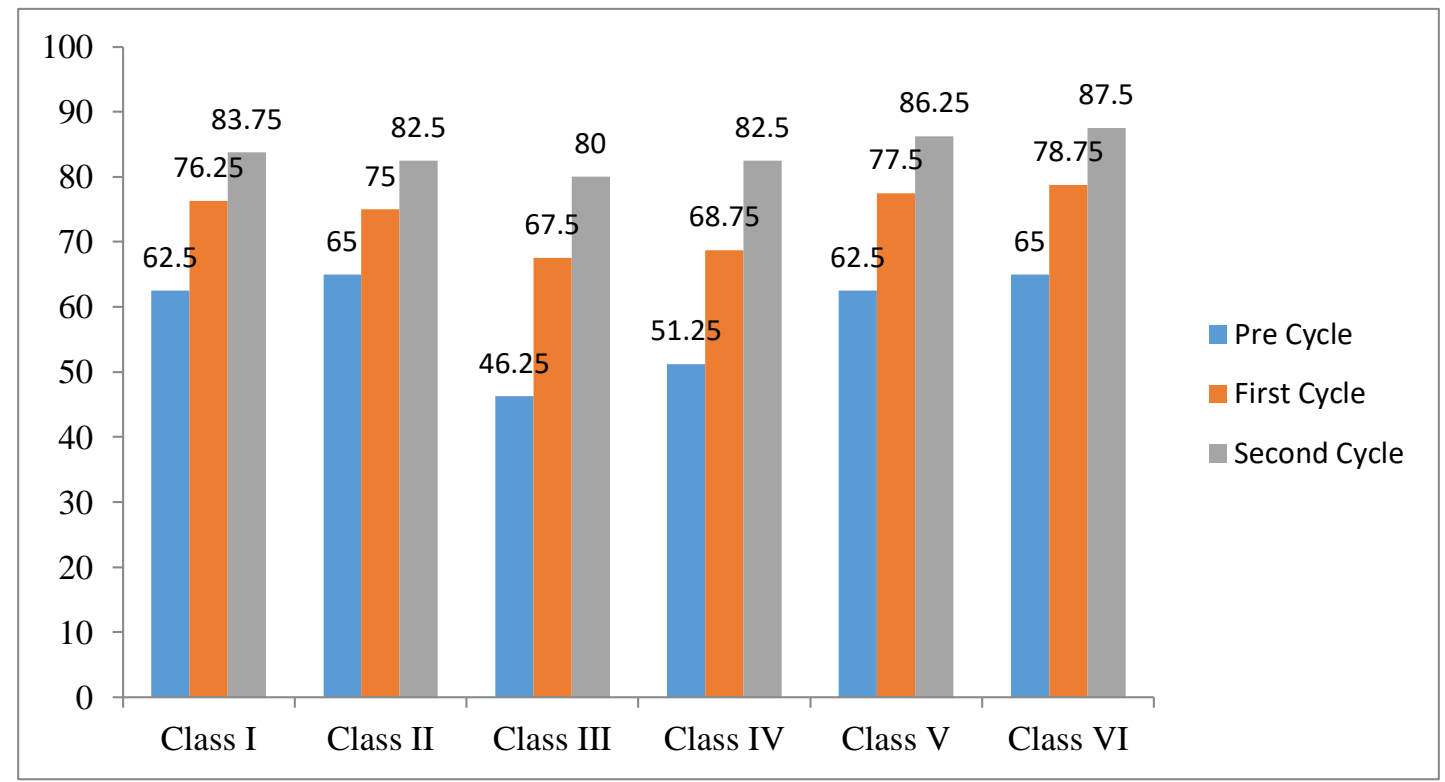

Figure 2 - Improving Classroom Teachers' Ability in During Preparing Program Worksheets

From the graph above, the ability of the six class teachers in preparing Student Worksheets for the Home Learning Program has increased significantly. All teachers who have completed a minimum of 75 . Thus, this school action research was stopped in second cycle.

\subsubsection{Reflection}


The results of the analysis show that the second cycle of action through mentoring began to be favored by class teachers in the student worksheet home learning program. This can be seen in the mentoring activities of the teachers who seemed enthusiastic about participating in the activity until the end.

The average ability of class teachers in preparing Student Worksheets for Home Learning Program after mentoring increased when compared to the previous condition. The ability of class teachers in the pre-cycle was only 58.75 then after mentoring by researchers increased to 73.96. And in the second cycle, individual mentoring was carried out increasing to 83.75 with completeness reaching $100 \%$.

\section{Discussion}

Based on the description of the results of the research above, that mentoring can improve the ability of classroom teachers in preparing Student Worksheets for the Home Learning Program. In the initial conditions, the researcher made observations on the Student Worksheet from Home Learning Program which had been compiled by 6 class teachers and obtained an average result of 58.75. In first cycle, the researcher provided classical Mentoring to 6 class teachers in compiling Student Worksheets for the Home Learning Program.

After the treatment in first cycle, the class teacher's ability to compile the Student Worksheet Home Learning Program. increased to 73.96 In second cycle, researchers provided individual Mentoring to 6 class teachers in preparing Student Worksheets for Home Learning Program. After the action in second cycle, the class teacher's ability to compile the Student Worksheet Home Learning Program increased to 83.75. We can see an increase in the average ability of class teachers in preparing Student Worksheets for the Home Learning Program we can see in the graph below:

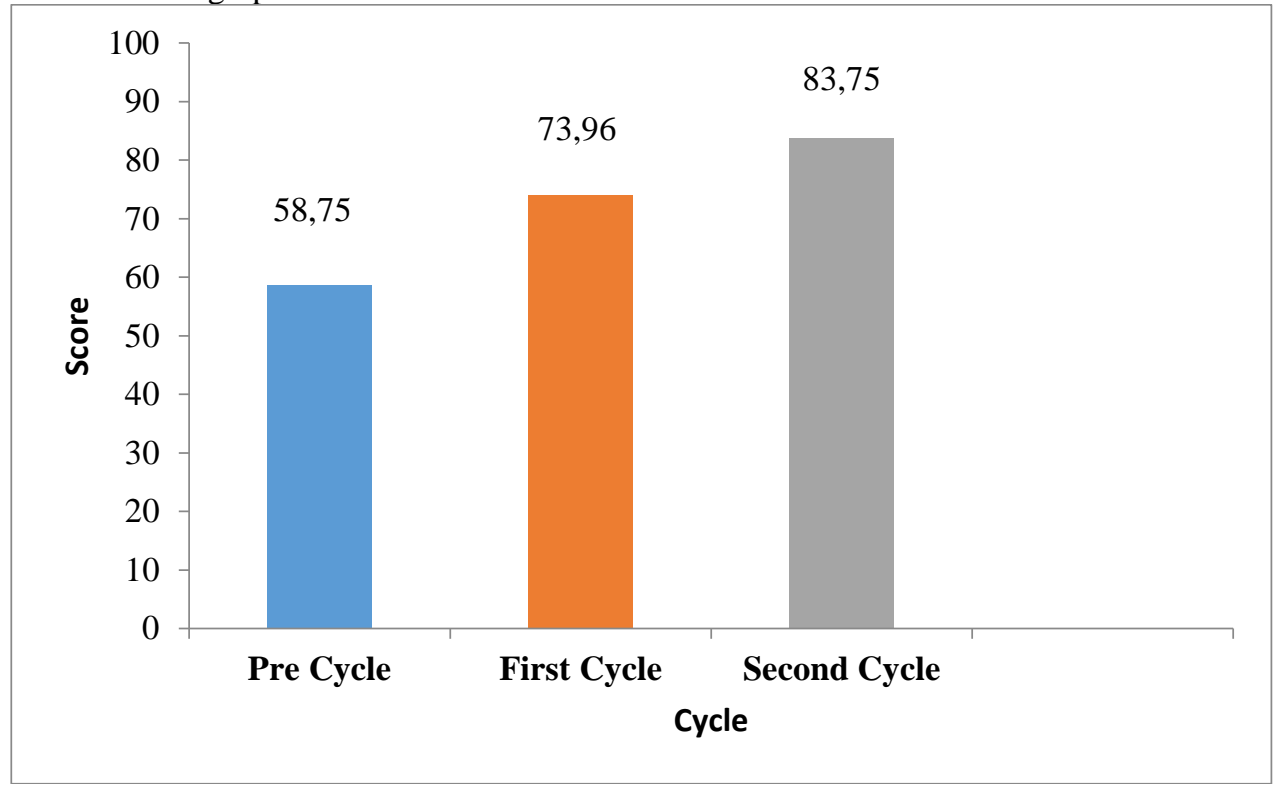

Figure 3 - The Increasing the Average Ability of Class Teachers in Compiling the Program Worksheets 
In addition to the increasing average ability of class teachers in preparing Student Worksheets for Home Learning Program, their completeness has also increased. Based on the results of observations made by researchers in the initial conditions, the completeness was very low, namely $0 \%$. Then in the first cycle the researcher provided classical Mentoring to 6 class teachers of Elementary School 3 Kebutuhduwur, and there was an increase in completeness by $67 \%$. Although completeness has increased significantly, the research success indicator has not yet reached $75 \%$. Thus, researchers continued this school action research into the second cycle. In the second cycle, researchers assisted by collaborators provided Mentoring individually and achieved $100 \%$ completeness.

The increase in teacher completeness in preparing Student Worksheets for the Home Learning Program we can see in the graph below:

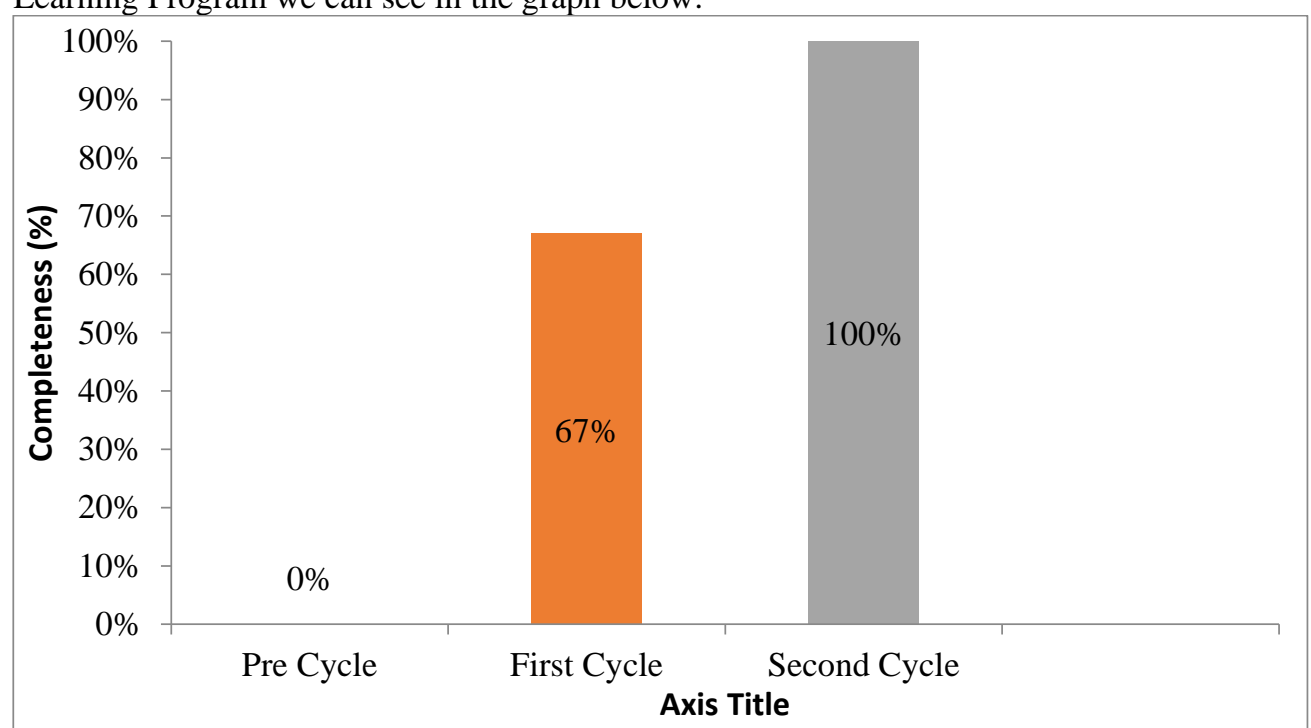

Figure 4 - Improving Classroom Teacher Compliance in Compiling Student Worksheets for Home Learning Program

After individual mentoring in second cycle, the class teacher's ability to prepare Student Worksheets for the Home Learning Program increased significantly. The average class teacher's ability in compiling worksheets reached 83.75 with $100 \%$ completeness. Thus, the results of this study can make a positive contribution in an effort to improve the ability of classroom teachers in preparing Student Worksheets for Home Learning Program through mentoring activities.

The increase in the average and completeness of the class teacher's abilities in preparing Student Worksheets for the Home Learning Program through mentoring is in line with Smith opinion which stated the mentor not only supports mentoring, but also challenges them to make improvements [11]. Fairbanks, Freedman and Kahn also argued, mentoring in teacher education is as complex as building and negotiating mentoring between teachers and teachers assisting students with various professional goals and in responding to the factors they face [13].

\section{Conclusion}


Through mentoring, the ability of class teachers in preparing Student Worksheets for Home Learning Program has increased from the initial condition which was only 58.75, increased to 73.96 in first cycle and increased again in Second Cycleto 83.75. Then, the completeness of class teachers in preparing Student Worksheets for the Home Learning Program has increased from the initial condition which was only $0 \%$ increased to $67 \%$ in first cycle and increased again in Second Cycleto $100 \%$. So, this action research can improve the ability of class teachers in preparing Student Worksheets for the Home Learning Program.

To improve the ability of teachers to prepare Student Worksheets for Home Learning Program, it is hoped that: (1) Teachers should make it a habit to compile Student Worksheets for Home Learning Program to support student learning; (2) Principal should provide to use varied learning models according to the current material and situation.

\section{References}

[1] Hermita N, Wijaya TT, Fauza N, Mulyani EA, Alim JA, Putra RA. The Important of the Community of Practice (CoP) in Improving the Primary School Teachers' Performance in Riau Province. Dinamika Jurnal Ilmiah Pendidikan Dasar. 2021 Apr 1;13(1):26-31.

[2] Amalia RR, Anggoro S, Eka KI. Identification of Teachers and Students' Readiness to E-Learning Implementation. JOURNAL OF TEACHING AND LEARNING IN ELEMENTARY EDUCATION (JTLEE). 2021;4(2):170-9.

[3] Ghate S, Parekh BJ, Thapar RK, Nadkarni PR, Sen S, Bansal U, Sambhariya CH, Popat S, Bhattacharya P, Kirtani S, Kanetkar Y. Indian Academy of Pediatrics Guidelines on School Reopening, Remote Learning and Curriculum in and After the COVID-19 Pandemic. Indian Pediatrics. 2020 Dec;57(12):1153-65.

[4] İnan C, Erkus S. The Effect of Mathematical Worksheets Based on Multiple Intelligences Theory on the Academic Achievement of the Students in the 4th Grade Primary School. Universal Journal of Educational Research. 2017;5(8):1372-7.

[5] Bhamani S, Makhdoom AZ, Bharuchi V, Ali N, Kaleem S, Ahmed D. Home learning in times of COVID: Experiences of parents. Journal of Education and Educational Development. $2020 \mathrm{Jul}$ 7;7(1):9-26.

[6] Mulyasa E. Menjadi Guru Professional Menciptakan Pembelajaran Kreatif dan Menyenangkan (Bandung: PT Remaja Rosdakarya). 2008.

[7] Arikunto S. Classroom action research. Jakarta: Bumi Aksara. 2010.

[8] Sugiyono. Metode Penelitian Pendidikan Pendekatan Kuantitatif,.Kualitatif, dan R\&D. Bandung: Alfabeta. 2018.

[9] Nurgiyantoro B. Penilaian Pembelajaran Bahasa. Yogyakarta: BPFE. 2010.

[10] Grogan P, Eviner V, Hobbie S. Keeping up with the Times: Equity Issue is Now Added to Our SelfReflection Worksheet for Improving Scientific Mentoring. The Bulletin of the Ecological Society of America. 2021 Apr 1;102(2).

[11] Smith K. Mentoring. InMentoring for Learning 2015 (pp. 283-298). SensePublishers, Rotterdam.

[12] Yuwono T, Andriani A. Activeness Analysis Learns Elementary School Student On Online Learning During The Pandemic. Dinamika Jurnal Ilmiah Pendidikan Dasar. 2021 Sep 22;13(2):93-6.

[13] Fairbanks CM, Freedman D, Kahn C. The role of effective mentors in learning to teach. Journal of teacher education. 2000 Mar;51(2):102-12. 